Tourism Research Journal

E-ISSN: 2958-9839

2020, Vol. 4 No. 2

\title{
Yogurt Favorite Level Test Using Basic Ingredients Soybean Milk With Addition of Green Spinach (Amaranthus Tricolor L.)
}

\author{
Johannes Kurniawan \\ Tourism Academy Bunda Mulia \\ jkurniawan@bundamulia.ac.id
}

\begin{abstract}
Spinach is food that is easily wilted and easily damaged, so spinach that has been harvested must be immediately marketed and consumed. There are two methods to extend the shelf life of spinach, namely cooling and drying methods. This study uses the drying method. The advantages of drying compared to cooling are that the dried material is more durable, the volume and weight are reduced, resulting in lower costs for packaging, transportation and storage. Along with the development of food technology, vegetable milk began to be introduced as an alternative ingredient for making yogurt whose nutritional value is not inferior to animal milk yogurt. In order to be more attractive to increase income and add coloring, the natural coloring is green spinach, considering there has never been researched into making yogurt with the addition of green spinach as a natural coloring. The treatment of adding green spinach vegetable extracts by $15 \%$ and $25 \%$ affects the quality changes that occur in yogurt made from soy milk. By simply differentiating the addition of $15 \%$ and $25 \%$ can prove the influence of changes in yogurt quality made from soy milk.
\end{abstract}

Keywords: Organoleptic Test, Yoghurt, Green Spinach, Soy Milk

Tourism Research Journal, Volume 4 (2), 2020 
Yogurt Favorite Level Test Using Basic Ingredients Soybean Milk

With Addition of Green Spinach (Amaranthus Tricolor L.)

\section{A. Introduction}

Spinach is one of the vegetables that is widely cultivated in Indonesia. This is because spinach is a vegetable that is very rich in vitamins and minerals. According to Dora (2010) Spinach is a vegetable commodity in great demand by Indonesians, from food sellers to housewives. This type of vegetable is used by Indonesian society because of its many health benefits. Spinach consists of several types including the type of spinach pull and spinach. But one of the most cultivated in Indonesia is spinach pull. The spinach has smaller stems and leaves than the spinach pick. The harvest period is shorter, only 3 weeks to 1 month after planting. Pulled spinach is usually made for spinach and spinach porridge soup.

Soybeans have played an important role as a source of vegetable protein, so soybeans are made in various forms of food. Several studies have looked for alternative grains with protein content that is almost equivalent to soybean seeds to be used as basic ingredients in some food products, such as Vegetable milk that is processed into fermented foods or drinks.

Yogurt is a dairy product fermented by bacterial microbes. Fermentation from lactose produces lactic acid which acts on milk protein, making yogurt denser and has a distinctive texture, flavor and aroma. Generally yogurt is made using cow's milk, but with the advancement of biotechnology yogurt can also come from vegetable milk, for example soyghurt raw material for milk (soy beans) and cocoghurt (coconut milk). Yogurt has many advantages, one of which can reduce the symptoms of lactose intolerance. During the fermentation of lactose content in yogurt goes down, so that the fermented milk is easier to digest, especially for lactose sufferers. Live bacteria in yogurt also produce the enzyme lactase needed to degenerate lactose into glucose and galactose. Yogurt is more durable than fresh milk (cow's milk) which can last for several days, even up to several weeks in cold conditions. This is due to lactic acid in yogurt functions like a natural preservative.

In this research, yogurt uses the basic ingredients of soybean milk which will be added with green spinach to add a degree of preference. The results of the study in the form of organoleptic quality test data for yogurt in the form of color, texture, aroma, and taste from several panelists whose data were taken based on analysis of variance showed that the addition of green spinach affects the preference level of yogurt made from soybean milk.. 
Yogurt Favorite Level Test Using Basic Ingredients Soybean Milk

With Addition of Green Spinach (Amaranthus Tricolor L.)

\section{B. Literature Review}

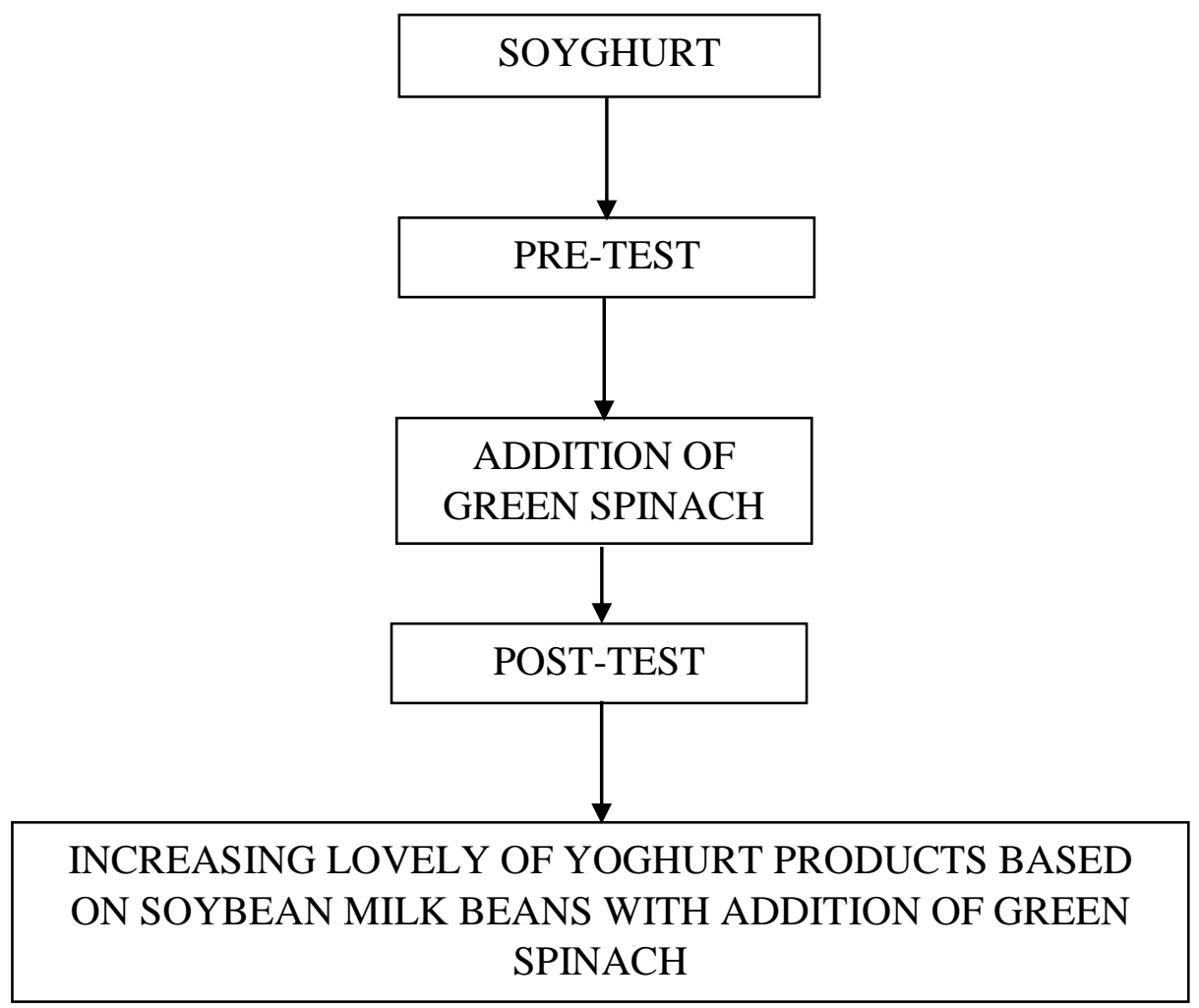

Figure 1. Framework

Source: Results of Author's Thought (2020)

\section{Milk}

Milk is the main source of nutrition for babies (ASI) before they can digest solid food. Animal milk (usually cow) is also processed into various products such as butter, yogurt, ice cream, cheese, sweetened condensed milk, milk powder and others for human consumption. Every individual needs milk to support life. Because the nutritional value contained in milk is very high, because it contains substances that are needed by the body such as protein, fat, carbohydrates, vitamins and mineral salts. In addition, milk is also easily digested and absorbed by the body, this makes milk a mainstay food in improving people's health and nutrition.

In addition to animal milk also known as vegetable milk such as milk from soybean raw materials produced in Yogyakarta under the name Saridele. Soybean was chosen as raw material for milk because it was considered to have a high nutritional content. Among the grains and beans. The protein content in soy milk is influenced by soybean varieties, the amount of water added, the duration and storage conditions, and heat treatment. The more amount of water used to thin the milk, the less protein content will be obtained. Protein levels in soy milk made with soybean ratio of $1: 8,1: 10$, and $1: 15$ are $3.6 \%, 3.2 \%$, and $2.4 \%$, respectively.

Tourism Research Journal, Volume 4 (2), 2020 
Yogurt Favorite Level Test Using Basic Ingredients Soybean Milk

With Addition of Green Spinach (Amaranthus Tricolor L.)

\section{Soy}

Soybean plants are included in the tribe Leguminosae or Papilionaceae. Shrub soybean plants, with stem height between $30-100 \mathrm{~cm}$. Two pieces of soybean seeds wrapped in seed shells. The color of the seed coat varies, there are yellow, black, green or brown. Soybean seeds are generally oval, round or flat. Seed size varies depending on variety (Suprapto, 2001). Soybean varieties developed in Indonesia can be seen in Table 1.

Table 1. Description of Soybean Varieties in Indonesia

\begin{tabular}{|c|c|c|c|c|}
\hline Varieties & Color & $\begin{array}{c}\text { Weight } \\
100 \text { pcs } \\
(\mathrm{g})\end{array}$ & $\begin{array}{c}\text { Protein } \\
\text { levels }(\%)\end{array}$ & $\begin{array}{c}\text { Fat level } \\
(\%)\end{array}$ \\
\hline Otau & Black & $7-8$ & 36.7 & 14.6 \\
\hline No. 27 & Black & $7-8$ & 40 & 11.7 \\
\hline No. 29 & yellow green & 7 & 43 & 9.3 \\
\hline Ringgit & Yellow & 8 & 39 & 20.1 \\
\hline Sumbing & Yellow & 8 & 39.3 & 19.4 \\
\hline Merapi & Black & 8 & 41 & 7.5 \\
\hline Shakti & yellow & $13-14$ & 41.6 & 16.1 \\
\hline Taichung & yellow & 10.5 & 39 & 20.9 \\
\hline TK 5 & Ivory & $13-15$ & 35.5 & 20.9 \\
\hline Orba & yellow & $12-14$ & 38.5 & 18.6 \\
\hline Galunggung & yellow & 12.5 & 44 & 19.9 \\
\hline Lokon & yellow straw & 10.76 & 34.3 & 15.8 \\
\hline Guntur & yellow & 10.53 & 30.53 & 18.4 \\
\hline
\end{tabular}

Source; Suprapto (2001)

\section{Soy milk}

Soy milk is the result of extraction from soy. Nutritional composition of soy milk is almost the same as cow's milk. Therefore, soy milk can be used as a substitute for cow's milk. Nutrient composition in soy milk and cow milk can be seen in Table 2.

Table 2. Nutritional Composition of Liquid Soy Milk And Cow's Milk (in 100 grams)

\begin{tabular}{lrr}
\hline Component & Soy milk & Cow's milk \\
\hline Water (\%) & 88.60 & 88.60 \\
Calories (Kkal) & 52.99 & 58.00 \\
Protein (\%) & 4.40 & 2.90 \\
Fat $(\%)$ & 2.50 & 0.30 \\
Carbohydrate $(\%)$ & 3.80 & 4.50
\end{tabular}

Tourism Research Journal, Volume 4 (2), 2020 
Yogurt Favorite Level Test Using Basic Ingredients Soybean Milk

With Addition of Green Spinach (Amaranthus Tricolor L.)

\begin{tabular}{lrr} 
Calcium (mg) & 15.00 & 100.00 \\
Phosphor (mg) & 49.00 & 90.00 \\
Sodium (mg) & 2.00 & 16.00 \\
Iron (mg) & 1.20 & 0.10 \\
Vitamin A (\%) & 0.02 & 0.20 \\
Vitamin B1 (\%) & 0.04 & 0.04 \\
Vitamin B2 (\%) & 0.02 & 0.15 \\
Saturated fatty acids (\%) & $40-48$ & $60-70$ \\
Unsaturated fatty acids & & \\
(\%) & $52-60$ & $30-40$ \\
Cholesterol (\%) & 0.00 & $9.24-9.9$ \\
Abu (gram) & 0.50 & 0.70 \\
\hline
\end{tabular}

Source: Cahyadi (2007)

According to Suprapti (2005), the activities carried out in the processing of soybeans into soy milk consist of several types, namely: crushing, dilution, boiling I, filtering, mixing ingredients, boiling II, bottling, and pasteurization. The sequence of activities in processing soybeans into soy milk can be explained as follows.

1. Destruction

Destroying activities carried out on soybeans that have undergone a softening process. Demolition activities use boiling water 10 times the weight of soybeans to be ground. Boiling water is splashed little by little during the process of crushing or grinding.

2. Dilution

Dilution is carried out to obtain soybean juice with a protein content of less than $7 \%$. The diluent used is boiling water remaining from the water used to flush soybeans in crushing activities.

3. Boiling 1

The diluted soybean juice is then boiled but not boiled (limited to 2 times on the surface of the foam).

4. Other ingredients added

Materials that can be mixed in the form of sugar, salt, vanilla, sodium benzoate, pandanus leaves, suspension stabilizers and coloring agents.

5. Boiling II

Boiling II is done on soy milk that has been mixed with other ingredients. The boiling process is done until it boils for 5 minutes.

6. Bottlers

Soymilk is packaged using sterile packaging bottles. Soy milk filling is carried out up to $99 \%$ of the maximum volume of packaging bottles.

Tourism Research Journal, Volume 4 (2), 2020 
Yogurt Favorite Level Test Using Basic Ingredients Soybean Milk

With Addition of Green Spinach (Amaranthus Tricolor L.)

7. Pasteurization

Pasteurization is done by steaming for 5 minutes and soaking in cold water until the temperature of the bottles and their contents are the same as room temperature.

\section{Yogurt}

Fermentation milk products can generally be divided into 2 groups, namely fermented milk products and cheese. Almost all of the initial constituents in fermented milk products still exist, with the exception of some of the constituents that have been metabolized by microorganisms. In cheese, a large portion of the initial milk's constituents is removed in the curd to obtain the final product. Meanwhile, one of the dairy products that have been developed is fermented milk, a term for a dairy product that is obtained through the fermentation process, a process of overhauling organic materials which is carried out with the help of enzymes produced by microbes. According to Afrianti (2013), yogurt is coagulated milk from the lactic acid fermentation process through the activities of Lactobacillus bulgaricus and Streptococcus thermophilus. Besides being made from fresh milk, yogurt can also be made from skim milk (nonfat milk) dissolved in water in a certain ratio depending on the thickness of the desired product. Apart from animal milk, yogurt can be made from a mixture of skim milk with vegetable milk.

Fermentation that occurs in the process of making fermented milk is lactic acid fermentation. This name was given because it produced lactic acid as a fermentation product from glucose. Lactic acid bacteria in milk are homofermentative lactic acid bacteria, for example Lactobacillus bulgaricus and Streptococcus thermophilus which produce lactic acid during glucose fermentation. Its ability to produce lactic acid is high in the fermentation process, fermentation products will be more durable, so fermentation is one way of preserving food, in this case milk. Lactic acid bacteria are usually used to improve milk quality and extend shelf life.

Symbiosis or mutual assistance between microorganisms during growth often occurs in foods containing 2 or more types of microorganisms. One type of microbe can produce metabolite products needed for the growth of other microorganisms that cannot produce it. In contrast, the second microorganism species produces a nutrient that stimulates the first microorganism to grow better. Symbiosis is found in the production of some fermented foods such as yogurt. Streptococcus thermophilus initially hydrolyzes milk protein by the enzyme extracellular proteinase and produces amino acids needed for the growth of Lactobacillus bulgaricus. In contrast, Lactobacillus produces formic acid which stimulates the growth of Streptococcus. Both types of bacteria are needed to produce the desired yogurt product.

Soyghurt is a beverage product made from soy milk which is produced through a fermentation process by lactic acid bacteria (LAB). The most

Tourism Research Journal, Volume 4 (2), 2020 
Yogurt Favorite Level Test Using Basic Ingredients Soybean Milk

With Addition of Green Spinach (Amaranthus Tricolor L.)

commonly used bacteria are Lactobacillus bulgaricus and Streptococcus thermophillus. This fermented milk is favored by the public because it tastes good and has many health benefits. Apart from being food, products made from milk are considered as products that can help digestion, prevent diarrhea, prevent an increase in blood cholesterol levels that are too high, and even stated to help fight cancer (Herawati and Wibawa, 2009).

\section{Description of Spinach Plant (Amaranthus tricolor L.)}

Spinach is a shrub and is approximately 1.5 meters high. The root system spreads at a depth of between $20-40 \mathrm{~cm}$ and has a taproot because it is a biseeded plant. Spinach is a plant that has a different morphology between types. Spinach is a type of leaf vegetable from the amaranthaceae family which has around 60 genera, and is divided into 800 species of spinach (Grubben, 1994). The scientific classification of spinach plants is as follows;

Kingdom: Plantae

Division : Spermathopyta

Class : Angiospermae

Subclass : Dicotyledone

Ordo : Caryophyllales

Family : Amaranthaceae

Genus : Amaranthus

Species : Amaranthus spp

\section{Food Quality}

Quality is not only found in goods or services, but also included in food products. Customers who come to look for food naturally want to buy quality food. According to Kotler and Armstrong (2012) product quality is a characteristic of a product or service that is in its ability to bear promises or inserts to satisfy customer needs. In this research what is sought is the quality of food products. According to Margareta and Edwin (2012), food quality is an important role in terminating consumer purchases, so it can be seen if food quality increases, then purchasing decisions will also increase.

According to Dita (2010) the quality of food products has an influence on customer satisfaction, so it would be better if it could improve and maintain the quality of food products as a basis for marketing strategies.

\section{Food Quality Dimensions}

According to West, Wood and Harger, Gaman and Sherrington and Jones in Margaretha and Edwin (2012) in general, the factors that influence food quality are as follows: 
Yogurt Favorite Level Test Using Basic Ingredients Soybean Milk

With Addition of Green Spinach (Amaranthus Tricolor L.)

1. Color

The colors of the ingredients must be combined in such a way that they do not look pale or the colors do not match. Color combinations are very helpful in consumer appetite.

2. Appearance

The phrase - looks good enough to eatll is not an exaggeration. Food must be well seen while on a plate, which is an important factor. The freshness and cleanliness of the food served is an important example that will affect the appearance of the food whether or not to be enjoyed.

3. Portion

In each serving of food the standard portion has been determined which is called the standard portion size.

4. Form

The form of food plays an important role in eye attractiveness. An interesting form of food can be obtained by cutting various foodstuffs, for example carrots which are cut in the form of dice or commonly called diced pieces combined with chiffonier cut lettuce which is an irregular cut in vegetables.

5. Temperature

Consumers like variations in temperature obtained from one food to another. Temperature can also affect the taste, for example the sweet taste in a food will be more felt when the food is still warm, while the salty taste in the soup will be less pronounced when the soup is still hot.

6. Texture

There are many food textures including smooth or not, liquid or solid, hard or soft, dry or moist. The level of thin and smooth and shape of food can be felt through the pressure and movement of receptors in the mouth.

7. Aroma

The aroma is a reaction from food that will affect consumers before consumers enjoy food, consumers can smell the food.

8. Maturity Level

The level of food maturity will affect the texture of the food. For example carrots that are boiled enough will be soft than carrots that are boiled faster. For certain foods such as steak everyone has their own taste about the level of steak maturity

9. Taste

The taste point of the tongue is the ability to detect the basis of sweet, sour, salty, bitter. In certain foods, these four flavors are combined to make one unique and interesting taste to be enjoyed.

\section{Research Design}

Research designs are ways that are used to collect research data so that research results can be proven. The author uses analysis techniques to analyze data obtained from research results. It aims to obtain accurate data according to

Tourism Research Journal, Volume 4 (2), 2020 
Yogurt Favorite Level Test Using Basic Ingredients Soybean Milk

With Addition of Green Spinach (Amaranthus Tricolor L.)

research objectives and find out the difficulties students face in producing complex procedure texts using discovery learning models.

In experimental research, there are several forms of design including preexperimental design, true experimental design, factorial design, and quasi experimental design. The design chosen by the researcher is quasi experimental design or quasi experiment. According to Sugiyono (2017), the quasiexperimental design has a control group, but it cannot fully control the outside variables that influence the implementation of the experiment.

\section{Research Methodology Types of research}

The method used in this study uses quasi-experimental methods. Experimental research is one type of quantitative research that is very powerful for measuring causal relationships. According to Sugiyono (2017) the experimental research method can be interpreted as a research method used to look for the effect of certain treatments on others under controlled conditions. Through research on the results of this experimental trial, the author tries to find quantitative data related to students' ability to write short stories. The data used to analyze the quantitative approach is data in the form of numbers.

\section{Variable}

The design of the preparation of the variable addition of Green Spinach is used in the study compiled as follows:

Po $=0 \%$ added

$\mathrm{P} 1=$ added $15 \%$

$\mathrm{P} 2=$ added $25 \%$

The number of repetitions is determined based on the Federner formula, namely;

$(\mathrm{t}-1)(\mathrm{r}-1) \geq 15$

Where it's:

$(\mathrm{t}-1)(\mathrm{r}-1) \geq 15$

$5 \mathrm{r} \geq 15+4$

$(6-1)(r-1) \geq 15 \quad 5 r \geq 19$

$5(\mathrm{r}-1) \geq 15 \quad \mathrm{r} \geq 19 / 5$

$5 \mathrm{r}-4 \geq 15 \quad \mathrm{r} \geq 3.8$ (rounded off $=4$ )

Information :

$\mathrm{t}=$ number of treatments

$r=$ number of repetitions

Based on this formula, the number of replications is 4 times, thus the total number of research units is: 6 levels $\mathrm{x} 4$ replications $=24$ research units.

\section{Population and Sample}

According to Sugiyono (2015), population is a generalization area that consists of: objects/subjects that have certain qualities and characteristics

Tourism Research Journal, Volume 4 (2), 2020 
determined by researchers to be studied and then drawn conclusions. Based on this theory, the population of this study is soy milk which is processed into yogurt.

According to Sugiyono (2015), the sample is part or number and characteristics possessed by the population. If the population is large, and researchers may not study everything in the population, for example due to limited funds, manpower and time, then the researcher will take a sample of that population. What is learned from the sample, the conclusion will be applied to the population. For this reason, samples taken from the population must be truly representative. The sample taken for this study was soybean milk used as yogurt and then added with Green Spinach Vegetables used in the experiment.

\section{Result}

Parameter Quality of Yogurt Texture Made from Soybean Milk with the addition of Green Spinach extract:

Table 3. Value Date Quality of Yogurt Texture Made from Soybean Milk Based on the Treatment of the Amount of Green Spinach extract

\begin{tabular}{|c|c|c|}
\hline $\begin{array}{c}\text { Treat The Amount of } \\
\text { Green Spinach Vegetable } \\
\text { Juice }\end{array}$ & Mean & $\begin{array}{c}\text { Indicator } \\
\text { (Texture) }\end{array}$ \\
\hline P0 $(0 \%)$ & 4.25 & Very Softer \\
P1 $(15 \%)$ & 4.17 & Very Softer \\
P2 $(25 \%)$ & 3.79 & Very soft \\
\hline Total Mean & $\mathbf{4 . 0 7}$ & \\
\hline \multicolumn{2}{|r}{} \\
\hline
\end{tabular}

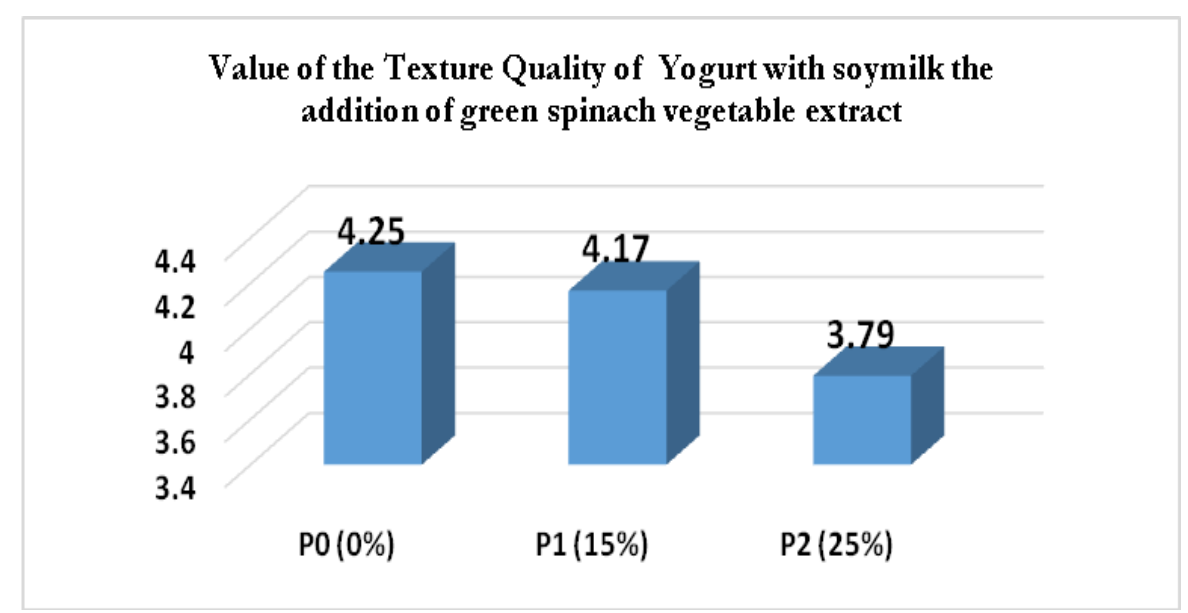

Figure 2. Organoleptic (Texture) Quality Test Chart Yogurt Made From Soy Milk Based on the treatment of the addition of Green Spinach Extract 0\%, 15\% and $25 \%$

Tourism Research Journal, Volume 4 (2), 2020 
Yogurt Favorite Level Test Using Basic Ingredients Soybean Milk

With Addition of Green Spinach (Amaranthus Tricolor L.)

Based on the data in Table 4, it can be seen that the average value of the yogurt texture quality for each treatment level indicates the variation of the data. This is evident in the average value of the quality of the texture of yogurt made from soy milk added with the highest green spinach vegetable extract is at $0 \%$ treatment of green spinach extract which has an average value of 4.25 with a very gentle indicator. The average value of yogurt's quality texture made from soybean milk added with the second highest green spinach vegetable extract at $15 \%$ treatment at 4.17 with a very softer indicator and the lowest is at $25 \%$ green spinach vegetable extract treatment at 3.79 with a very soft indicator. Parameters Quality Aroma Yogurt Made from Soybean Milk Milk with the addition of Green Spinach Vegetable extract:

Table 4. Date Value of Aroma Quality of Yogurt Made from Soybean Milk Based on the Treatment of the Amount of Green Spinach extract

\begin{tabular}{|c|c|c|}
\hline $\begin{array}{c}\text { Treat The Amount of } \\
\text { Green Spinach Vegetable } \\
\text { Juice }\end{array}$ & Mean & $\begin{array}{c}\text { Indicator } \\
\text { (Aroma) }\end{array}$ \\
\hline P0 $(0 \%)$ & 4.38 & Very fond of it \\
P1 $(15 \%)$ & 3.88 & Love it \\
P2 $(25 \%)$ & 4.25 & Very fond of it \\
\hline Total Mean & $\mathbf{4 . 1 7}$ & \\
\hline
\end{tabular}

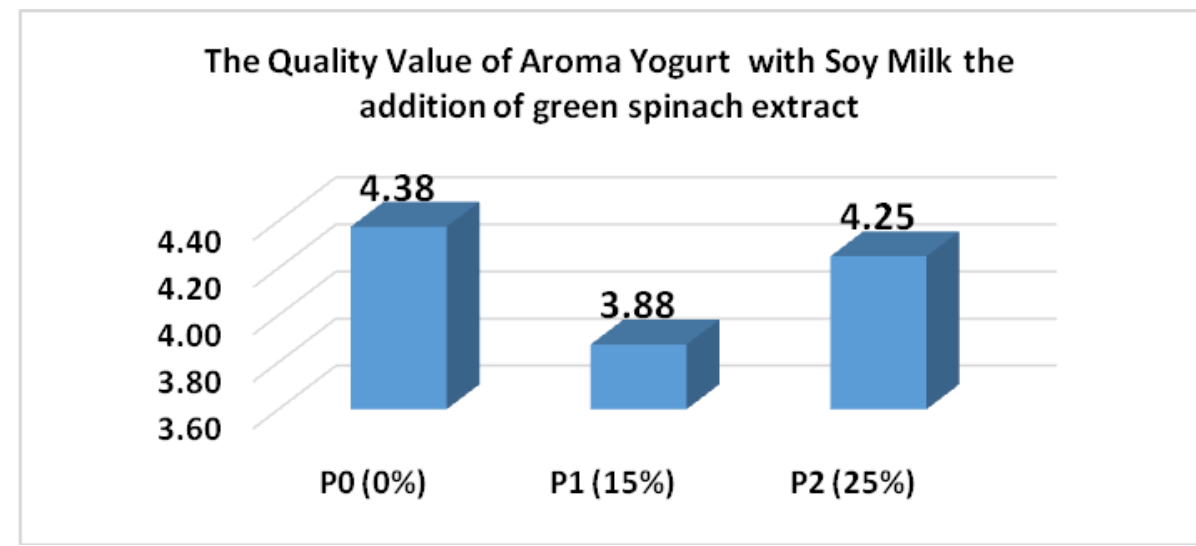

Figure 3. Graph of Organoleptic Quality Test (Aroma) Yogurt Made From Soy Milk Based on the treatment of the addition of Green Spinach Extract 0\%, 15\% and $25 \%$

Based on the data in Table 4, it can be seen that the average value of the aroma quality of yogurt for each level of treatment indicates the variation of the data. This is evident in the average value of the quality of the aroma of yogurt made from soy milk added with green spinach extract is the highest in the treatment of $0 \%$ green spinach extract which has an average value of 4.38 with

Tourism Research Journal, Volume 4 (2), 2020 
Yogurt Favorite Level Test Using Basic Ingredients Soybean Milk

With Addition of Green Spinach (Amaranthus Tricolor L.)

very fond indicators. The average value of the aroma quality of yogurt made from raw soybean milk was added with the second highest among green spinach extract at $25 \%$ treatment by 4.25 with a very fond indicator and the lowest was the $15 \%$ green spinach vegetable extract treatment at 3.88 with a very fond indicator. Parameter of Color Quality Yogurt Made from Soybean Milk Milk with the addition of Green Spinach extract:

Table 5. Color Value Date of Yogurt Made from Soybean Milk Based on the Treatment of the Amount of Green Spinach extract

\begin{tabular}{|c|c|c|}
\hline $\begin{array}{c}\text { Treat The Amount of } \\
\text { Green Spinach } \\
\text { Vegetable Juice }\end{array}$ & Mean & $\begin{array}{c}\text { Indicator } \\
\text { (color) }\end{array}$ \\
\hline P0 $(0 \%)$ & 4.33 & irresistible \\
P1 $(15 \%)$ & 3.25 & Very interesting \\
P2 $(25 \%)$ & 4.29 & irresistible \\
\hline Total Mean & $\mathbf{3 . 9 6}$ & \\
\hline
\end{tabular}

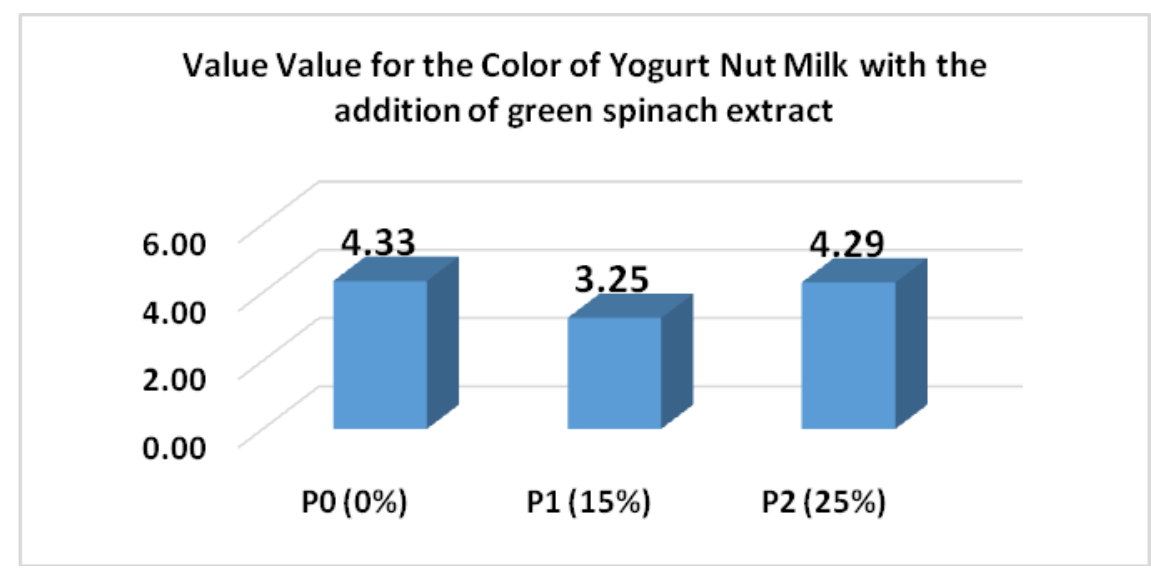

Figure 4. Organoleptic Quality Test Chart (Color) Yogurt Made from Soy Milk Based on the treatment of the addition of Green Spinach Extract $0 \%, 15 \%$ and $25 \%$

Based on the data in Table 5 , it can be seen that the average value of the yogurt color quality for each treatment level indicates the variation of the data. This is evident in the average value of yogurt's color quality made from soy milk added with green spinach vegetable extract, which is highest in the treatment of $0 \%$ green spinach vegetable extract, which has an average value of 4.33 with irresistible indicators. The average value of the color quality of yogurt made from raw soybean milk added with the second highest green spinach vegetable extract at $25 \%$ treatment by 4.29 with a irresistible indicator and the lowest is the treatment of green spinach extract $15 \%$ by 3.25 with very interesting indicators. Parameter of the Quality of Yogurt Flavor Made from Soybean Milk with the addition of Green Spinach Vegetable extract:

Tourism Research Journal, Volume 4 (2), 2020 
Yogurt Favorite Level Test Using Basic Ingredients Soybean Milk

With Addition of Green Spinach (Amaranthus Tricolor L.)

Table 6. Date Value of The Quality of Yogurt Taste Made From Soybean Milk Based on The Treatment of The Amount of Green Spinach Extract

\begin{tabular}{|c|c|c|}
\hline $\begin{array}{c}\text { Treat the amount of green } \\
\text { spinach vegetable juice }\end{array}$ & Mean & $\begin{array}{c}\text { Indicator } \\
\text { (Taste) }\end{array}$ \\
\hline P0 (0\%) & 4.5 & Very fond of it \\
P1 $(15 \%)$ & 4.08 & Love it \\
P2 $(25 \%)$ & 4.46 & Very fond of it \\
\hline Total Mean & 4.35 & \\
\hline
\end{tabular}

\section{Value of the Quality of Yogurt Soybean Milk Flavor with the addition of green spinach extract}

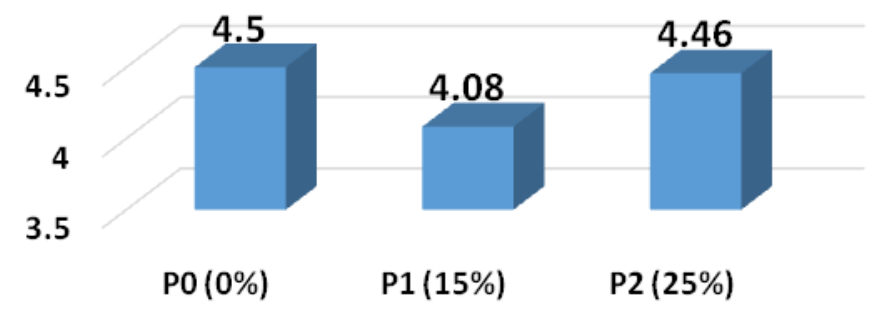

Figure 5. Organoleptic Quality Test Chart (Taste) Yogurt Made From Soy Milk Based on the treatment of the addition of Green Spinach Extract $0 \%, 15 \%$ and $25 \%$

Based on the data in Table 6 , it can be seen that the average value of the quality of the yogurt flavor for each treatment level indicates the variation of the data. This is evident in the average value of the quality of the flavor of yogurt made from soy milk added with the highest green spinach vegetable extract is in the treatment of $0 \%$ green spinach vegetable extract which has an average value of 4.5 with indicators very fond. The average value of the quality of the yogurt made from raw soybean milk added with the second highest green spinach extract at $25 \%$ treatment by 4.46 with very fond indicator and the lowest is the treatment of green spinach extract $15 \%$ by 4.08 with very like indicator once.

\section{E. Discussion}

The results of research on making yogurt using a substitute for soybean milk by adding spinach extract as a variant of flavor. Where from this addition is intended for the manufacture of yogurt made from soy milk add spinach variant.

From the results of the distribution of products and questionnaires, it can be seen that the variant can be accepted by the relevant respondent. At the level of preference, it is seen that the respondents like the variant. However, it appears that many of the respondents are more inclined to choose original products compared to the products that added the spinach taste.

Tourism Research Journal, Volume 4 (2), 2020 
Yogurt Favorite Level Test Using Basic Ingredients Soybean Milk

With Addition of Green Spinach (Amaranthus Tricolor L.)

\section{F. Conclusion}

Based on research conducted by the author on organoleptic testing of yogurt made from soy milk based on the addition of green spinach vegetable extract, it was concluded that;

1. The treatment of adding green spinach extract by $15 \%$ and $25 \%$ affects the quality changes that occur in yogurt made from soy milk. By simply differentiating the addition of $15 \%$ and $25 \%$ can prove the influence of changes in yogurt quality made from soy milk.

2. With an organoleptic test, respondents are more likely to say that the texture, aroma, color and taste of yogurt made from soybean milk added with green spinach vegetable extract can be accepted and consumed like yogurt in general.

\section{REFERENCES}

Afrianti, Leni Herliana. (2013). Teknologi Pengawetan Pangan. Bandung: Alfabeta. Cahyadi, W. (2007). Teknologi dan Khasiat Kedelai. Jakarta: Bumi Aksara.

Dita, Amanah. (2010). Pengaruh Harga, dan Kualitas Produk terhadap Kepuasan Konsumen pada Majestyk Backry \& Cake Shop Cabang H.M Yamin Medan. Jurnal Pendidikan Ekonomi, Vol 2, No 1, Universitas Negeri Medan.

Dora, Fatma Nurshanti. (2010). Pertumbuhan dan Produksi Tanaman Sawi (Brasicca Juncea L) dengan Tiga Varietas Berbeda. Agronobis, (Vol. 2, No. 4, September 2010, ISSN: 1979-8245X, Hal: 7-10).

Grubben, G. J. H., \& S. Sukprakarn. (1994). Plant Resourches of South-East Asia No 8 Vegetables. PROSEA, Bogor, Indonesia.

Herawati, DA., \& Wibawa, DAA. (2009). Pengaruh Konsentrasi Susu Skim dan

Waktu Fermentasi Terhadap Hasil Pembuatan Soyghurt. Jurnal Ilmiah Teknik Lingkungan Vol. 1(2).

Kotler, Philip., \& Gary, Amstrong. (2012). Prinsip-prinsip Pemasaran. Jakarta: Erlangga.

Margaretha S., \& Edwin Japarianto (2012). Analisa Pengaruh Food Quality \& Brand Image terhadap Keputusan Pembeli Roti Kecik Toko Roti Ganep's di Kota Solo. Jurnal Manajemen Pemasaran.

Sugiyono. (2015). Metode Penelitian Manajemen. Bandung: Alfabeta.

Sugiyono. (2017). Metode Penelitian Kuantitatif, Kualitatif, dan R\&D. Bandung: Alfabeta.

Suprapto. (2001). Bertanam Kedelai. Jakarta: Penebar Swadaya.

Suprapti, M. L. (2005). Pembuatan Tabu. Kanisius: Yogyakarta.

Tourism Research Journal, Volume 4 (2), 2020 